\title{
Ethicists and biologists ponder the price of eggs
}

\section{倫理学者と生物学者で卵子の值段を思案する}

Nature Vol. 442(606-608)/10 August 2006

ヒトの卵子が足りないと幹細胞研究は進まない。卵子提供の対価を女性に支払うことで卵子の供給量は増えるだろうが、 そうした方策の利点や長期的な健康への影響については専門家の間でも意見が分かれている。

研究のために卵子を提供した女性に、 費やした時間や被った不快感、健康へ のリスクなどに応じた対価を支払うべ きだろうか。世界最大の幹細胞研究者 団体がこの問題に取り組んでおり、現 在、一般の人々に意見を求めている。

幹細胞研究者たちが卵子を欲しがるの は、体細胞核移植もしくは「治療用クロー ン作製」の研究を行うためである。患者 の細胞核をヒトの卵子に移入して、その 卵子を胚まで発生させ、そこから細胞を 採ることで、その患者のもつDNA に適 合した胚性幹細胞を得ようとしているの だ。この技術が医療面にもたらす可能性 は非常に大きい。しかし研究者たちはこ れをほとんど実行できない状況に置かれ ており、その主な制約要因は使用できる ヒト卵子の数に限りがあることだ。

これまで研究者たちは、不妊治療を 受けた女性から余った卵子を研究用に 提供してもらっていた。しかし、その 供給量は微々たるものである。こうし た女性たちへの説得を助けるため、い くつかの研究室ではしだいに、不妊治 療費の割引といった金銭的な報酬を申 し出るようになってきている。またほ かに、健康な女性に卵子提供を依頼し 始めている研究室もあり、こうした健 康な女性にどういう形で報酬を支払う べきかという議論を引き起こしている。

倫理学者の中には、女性は卵子提供 に伴う不快感や労力への報酬を受け取
るべきだと主張する学者もいれば、こ うした報酬が特に貧しい女性に対して 卵子提供を強要する不適切な誘因を作 り出してしまうのではないかと懸念す る学者もいる。卵子採取処置の長期的 な健康リスクに関してはほとんどわ かっていないことも、事態をいっそう ややこしくさせている。

欧州やアジア、中東や北米など、多 くの国々の研究者たちが研究用の卵子 提供を女性に依頼しているが、そのや り方はみな異なっている。北東イング ランド幹細胞研究所の研究者たちは 7 月 27 日に、研究用卵子を提供した女性 に対して体外受精の費用の一部を肩代 わりすることについて、英国ヒト受精 · 胚機構（HFEA）から承認を受けたと発 表した（Nature 442,498; 2006）。

しかし、研究用卵子の提供を受けて いるスウェーデンなど他の欧州諸国で は、直接経費以外の金銭の支払いを禁 止している。日本は面倒な事態に陥る リスクを理由に卵子提供を一切禁止し ているが、中国その他の数か国はこの 問題にとりたてて取り組んではいない。

米国では昨年、米国科学アカデミー の識者会議が、女性には直接経費だけ を支払うべきだとする勧告を出した。こ のやり方は、カリフォルニア再生医療研 究所 (CIRM) や、ハーバード幹細胞研 究所のあるマサチューセッツ州ですでに 導入されている (Nature doi:10.1038/ news060605-6; 2006 参照)。どちら の研究所でも現在、研究用の卵子提供 を健康な女性に依頼しているが、両者の 方針は異なっている。例えば、カリフォ ルニア州の法律では州外から卵子提供の ためにやってきた女性の交通費支払いが 認可されており、他方、ハーバードがど うやってこの問題に対処しているのかは はっきりしない。「現在のところ、我々 は提供者探しをこの地域に限定していま す」と広報担当の B. D. Colen は話す。

研究者たちが望むのは、研究材料の出 所について心配することなく材料を共有 できるような世界共通のガイドラインで ある。そこで、国際幹細胞学会 (ISSCR) の特別委員会は、ガイドライン作成に向 けたいっそうの努力の一環として、金銭 的補償の問題を検討中である。この特別 委員会は、14 か国にわたる科学者、倫 理学者、法律家からなり、昨年、韓国の 幹細胞研究者Woo Suk Hwang (黄禹 錫）の科学的不正の発覚を受けて招集さ れた。彼は、治療用クローン作製技術に よって 11 のヒト胚性幹細胞株を得たと する証拠をねつ造しただけでなく、卵子 を提供した数百人の女性たちへの金銭的 支払いについても偽っており、自分の部 下の女性たちから卵子を得ていた。

6 月 30 日、ISSCR の特別委員会はト ロントで開催された年次総会でガイドラ イン草案を公表した。このガイドライン には、米国科学アカデミーが昨年提案し 


\section{卵子提供にあたって受ける処置}

1. 1 回あたりの典型的手順では、女 性がゴナドトロピン放出ホルモン 作動薬を 1 ～週間にわたって毎 日服用し、下垂体による排卵刺激 を抑える。

2. 続いて、卵子を含む卵胞をいくつ か発達させるために、卵胞刺激ホ ルモンなどのゴナドトロピンを注 射する。

3. 第 3 のホルモンで、卵子の最終的 な成熟を促進する。

4. 針を膣壁経由で卵巣へ差し入れて、 卵子を採取する。

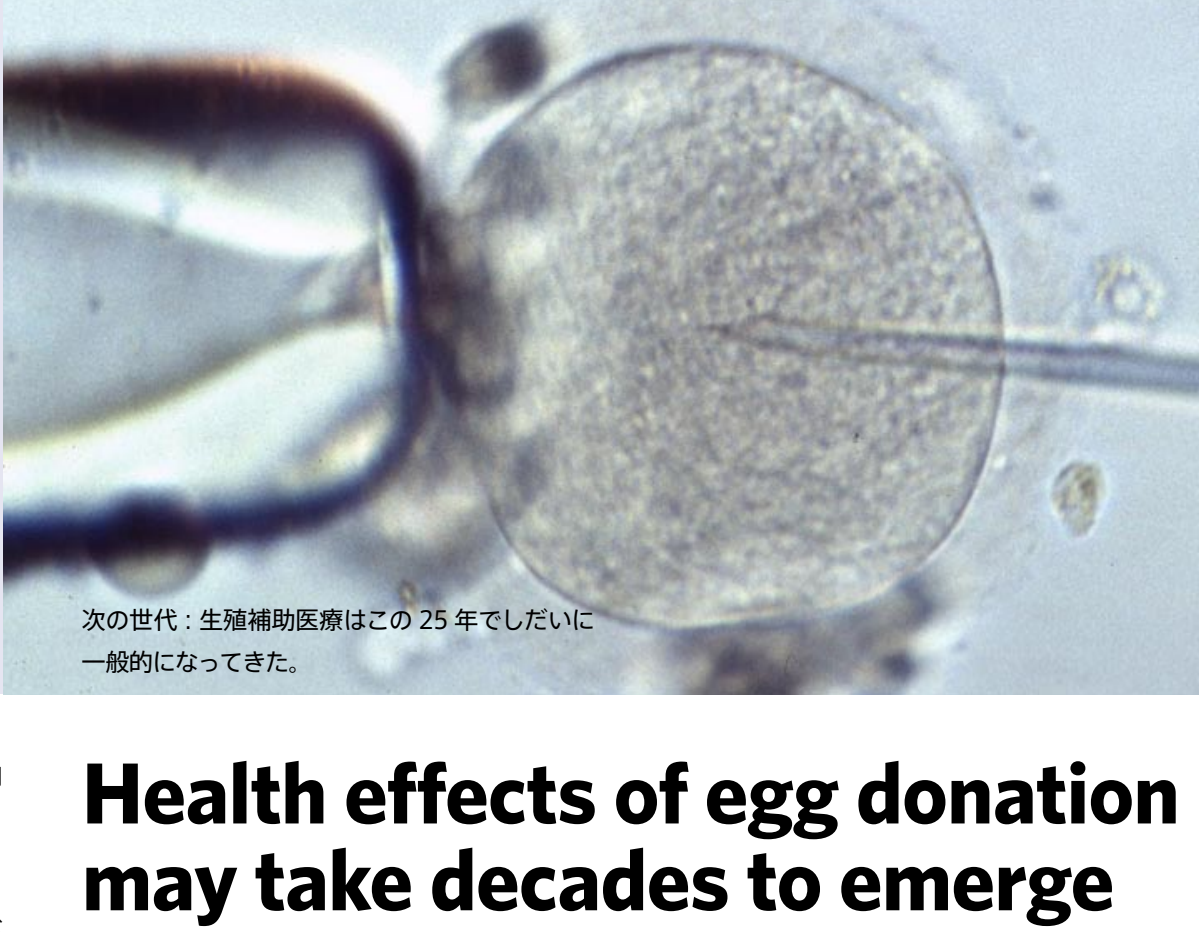

た原則の大部分を織り込んであるが、卵 子提供の問題についてはそうではない。 同委員会は、対価の支払いに関してもっ と進歩的な方針を設ける余地を残してお り、幹細胞研究の計画はその地域の監視 団体によって再検討されるべきだと提言 するにとどめている。こうした団体が、 「ヒト生体材料の提供にあたって不適切 な勧誘や他の不適切な影響がない」こと を保証してくれるはずである。何をもっ て「不適切」とするかは、各地域の監視 団体に委ねられる。

ハーバード大学医学系大学院の生物 学者で同委員会の議長を務めるGeorge Daleyによれば、これが委員会が達す ることのできた最善のコンセンサスな のだという。というのも、委員会の科学 者や倫理学者たちは、卵子提供者をど う扱うべきかについて、はっきりした意 見の一致に至らなかったからだ。

とはいえ、今回のガイドラインは重要 な第一歩とみなされ、現在、ISSCR は一 般からの意見を 9 月 1 日まで受け付けて おり、その後文書にまとめる予定である。 「これらのガイドラインは、完全に研究 者たち自身の手による規則だとみなされ ようになるだろう」とハーバード幹細胞 研究所の Kevin Eggan はいう。「研究者 たちがこれらの問題についてちゃんと考 えているということを世間に知らしめる のは、非常に有益なことなのです」。 Erika Check

\section{卵子提供の健康への影響が明らかになる のは数十年先のことかもしれない}

1989 年のこと、32 歳の健康な女性が不 妊症の妹に自分の健康な卵子をいくつか 提供し、赤ん坊を得るチャンスを授けた。 ロンドンにあるクロムウエルIVF 不妊治 療センターの医師たちは、この姉に、卵 巣の一群の卵子を成熟させるホルモン類 を投与し、受精用の卵子を 6 個採取した。 妹には 3 個の胚が移植され、2 個は凍結 保存された。女の赤ん坊が 1 人生まれた。

それから 5 年後、凍結保存した胚を 廃棄するかどうか尋ねようと、医師た ちは卵子を提供した姉に連絡をとった。 すると、彼女は後期の結腸がんで、頭 骨にも転移していると診断されている ことがわかった。彼女は 39 歳の誕生日 を目前にして亡くなった。

排卵誘発剂がこの女性のがんを引き起 こしたのかどうか、あるいは加速させた のかどうかは、医師たちにもわからない。 だが、その可能性はあることから、クロ ムウエルの不妊治療専門医である Kamal Ahuja はこの症例を報告し、卵子提供の リスクについてわかっていることがいか
に少ないかを知らしめようとした（K.E Ahuja and E. G. Simons, Hum. Reprod. 13，227-231；1998)。「これには我々全 員が衝撃を受けました」と彼は語る。

生殖医療の専門医たちの話では、排卵 誘発に使われる薬剤の長期的リスクにつ いては不十分な情報しかないという。体 外受精 (IVF) や生殖補助医療の急増に 伴って、排卵誘発はこの 25 年の間にあ りふれた処置法となった。しかし一部の 研究では、排卵誘発剂が特定のがんの発 生につながる可能性が示唆されている。

この問題は現在、改めて綿密に調べ られつつある。今や、研究者が健康な 女性に幹細胞研究用の卵子を提供して もらうということは、赤ん坊を授ける ことなく彼女たちを排卵誘発の潜在的 なリスクにさらすことになるからだ。 この問題を議論するため、サンフラン シスコにあるカリフォルニア再生医療 研究所 (CIRM) は、9月開催予定の会 議に専門家たちを招集した。英国のヒ 卜受精·胚機構 (HFEA) も、研究用の 